\title{
〔93 94〕ビニル系共重合体の溶液に関する研究
}

第 1 報 酢酸ビニル-塩化ビニル共重合体の溶液浸透圧および溶液粘度

(1956 年 12 月 17 日受理)

中島章夫*・外林秀 人 $^{*}$. 桜田一郎*

要 旨共重合体組成を異にする酷酸ビニルー塩化ビニルのシクロヘキサハン溶液に関して, 溶液浸透圧, 粘度の測定 を行い，高分子の分子量上極限粘度数の関倸，溶液中に扔ける溶解状態の共重合体組成侤存性を熟力学的に検即した。

\section{緒言}

以前の研究1)においてわれわれは酶酸ビニル(VAc) と塩化ビニル(VC)の共重合体について浸透圧その他 の測定を行ったが，本報告では共重合体組成の全領域で試料を調製し，それらの分別物から重合度がほぼ同 一であるような試料を選んで，主として希薄溶液の熱力学的性質の組成依存性を検討する。

\section{1. 試料の調製および測定}

過硫酸ソーダ水溶液に第 1 表に示すような比で VAc および VC を添加し， $50^{\circ} \mathrm{C}$ の恒温槽中で容器を回 転させつつ 30 時間重合を行った。重合物は蒸留水で募浄，洗浄をくり返し，40〜50 $\mathrm{C}$ で減圧乾燥し，つい で表に示した系によって分別した。すなわち PVAc および PVC ではテトラハイドロフラン (THF)に溶解 させて水で沈殿させたが，共重合体ではェタノール，ベンゼンの順にその沸点で可溶部を抽出し，しかる後残 部について THF-水系の分別を行った。分別試料はカリウス法で VC 含率を求めた。

第 1 表 試料の重合および分別条件

単量体: 水 $=1: 2$, 過硫酸ソーダ $2^{\circ} \%$ (対単量体), $50^{\circ} \mathrm{C}, 30$ 時間重合

\begin{tabular}{|c|c|c|c|c|}
\hline $\begin{array}{l}\mathrm{VC} \\
\text { (cc) }\end{array}$ & $\begin{array}{l}\text { VAc } \\
\text { (cc) }\end{array}$ & $\begin{array}{c}\begin{array}{c}\text { 重合收率 } \\
(00)\end{array} \\
\end{array}$ & 分 別 系 & 試料 記 号 \\
\hline 0 & 10.0 & 60 & THF-水 & PVAc-F3 \\
\hline 2.0 & 8.0 & 90 & エタノール, ベンゼン, $\mathrm{THF}$-水 & A-F3 \\
\hline 4.0 & 6.0 & 80 & 同 上 & $\mathrm{B}-\mathrm{F} 2, \quad \mathrm{~B}-\mathrm{F} 5$ \\
\hline 6.0 & 4.0 & 85 & 同 上 & $\mathrm{C}-\mathrm{F} 2$ \\
\hline 10.0 & 0 & 93 & $\mathrm{THF}$-水 & PVC-F3 \\
\hline
\end{tabular}

得られた分別試料はシクロへキサノンに溶解させ，前報”を考虑し $105^{\circ} \mathrm{C} て ゙ 8$ 時間加温後測定に供した。

粘度の測定はオストワルド型粘度計で常法により行い，浸透圧測定はZ Zimm-Meyerson 型浸透圧計を用 い半透膜としてはコロジオン膜を脱的して使用した。シクロへキサノンに対する使用膜の透過度 $P_{e r}$ は約 $21 \times 10^{-7}$, 比透過度 $P_{s p}$ は $12 \times 10^{-12}$ 程度であり透過性は良好である。

\section{2. 共重合体の重合度}

われわれは以前の報告で共重合体の重合度 $P$ と極限粘度数の間に次の関係を経験的に見出し，

* 京都大学工学部㵶維化学教室 (京都市左京区吉田) 


$$
P=\left[\operatorname{antilog} \frac{[\eta]}{\left\{0.2 x^{m}+0.35(1-x)^{m}\right\}}-1\right]\left\{500 x^{m}+2000(1-x)^{m}\right\} \quad m=0.833
$$

共重合体中の塩化ビニルのモル分率 $x$ の 0.4 以上の範囲につき，われわれ自身のデータおよび Staudinger

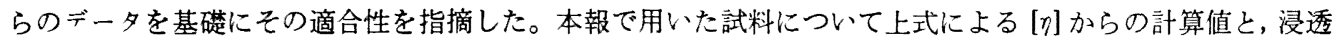
圧測定から得られた (第 3 表参照) 值を比較して示すと第 2 表のように提案した (1) 式が支障なく適用しらるこ 上が見出された。

第 2 表 試料の VC 含率と粘度ならびに浸透圧から求められる重合度

\begin{tabular}{|c|c|c|c|c|}
\hline & \multirow{2}{*}{$x$ (VC モル分率) } & \multirow{2}{*}{$\begin{array}{c}{[\eta]} \\
\left(\text { シクロヘキサノン, } 30^{\circ} \mathrm{C}\right)\end{array}$} & \multicolumn{2}{|c|}{$P($ 重合度 $)$} \\
\hline & & & (1) 式より & 浸透圧より \\
\hline PVAc-F3 & 0 & 0.080 & 1380 & 1310 \\
\hline $\mathrm{A}-\mathrm{F} 3$ & 0.264 & 0.060 & 850 & 840 \\
\hline B-F5 & 0.407 & 0.068 & 960 & 990 \\
\hline $\mathrm{C}-\mathrm{F} 2$ & 0.686 & 0.065 & 800 & 910 \\
\hline PVC-F3 & 1.000 & 0.099 & 1060 & 1100 \\
\hline
\end{tabular}

\section{3. 浸透圧の第 2 ビリアル係数の共重合体組成依存性}

シクロへキサノンは酶酸ビニルー塩化ビニル共重合体のすべての組成の高分子に対し共溶性があるから，第

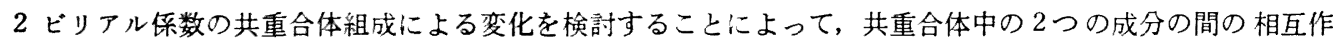
用を論じ，それらによって共重合体の溶解状態を論義することができるわけである。浸透圧の測定值ならび にそれらから求められた第 2 ビリアル倸数 $A_{2}$, さらに Flory-Huggins 式における相互作用倸数 $れ$ $A_{2}=R T(0.5-\not) / 1000 V_{1} d_{2}{ }^{2}$ から求め, 一括して第 3 表你す。 $V_{1}$ は溶媒のモル容積で, 溶質密度 $d_{2}$ は次 報で論義する溶液中にち污る共重合体の見かけの比容積から求めて用いた。

第 3 表 VAc-VC 共重合体シクロヘキサノン溶液の浸透圧のデータ, $30^{\circ} \mathrm{C}$

\begin{tabular}{|c|c|c|c|c|c|c|}
\hline & $C=(\mathrm{g} / \mathrm{l})$ & $\pi(\mathrm{atm}) \times 10^{3}$ & $\frac{\pi}{C}\left(\frac{\mathrm{atm} \cdot \mathrm{l}}{\mathrm{g}}\right) \times 10^{\mathrm{s}}$ & $M$ (分子量) & $A_{2} \times 10^{4}$ & $\chi$ \\
\hline $\begin{array}{c}\text { PVAc-F3 } \\
(x=0)\end{array}$ & $\begin{array}{r}5.99 \\
3.99 \\
2.00 \\
\lim 0\end{array}$ & $\begin{array}{l}1.32 \\
1.03 \\
0.38\end{array}$ & $\begin{array}{l}0.221 \\
0.258 \\
0.190 \\
0.200\end{array}$ & 112,900 & 1.61 & 0.477 \\
\hline $\begin{array}{l}\text { A-F3 } \\
\quad(x=0.264)\end{array}$ & $\begin{array}{r}5.86 \\
3.91 \\
1.95 \\
\lim 0\end{array}$ & $\begin{array}{l}3.25 \\
1.96 \\
0.92\end{array}$ & $\begin{array}{l}0.555 \\
0.500 \\
0.469 \\
0.440\end{array}$ & 66,950 & 7.23 & 0.392 \\
\hline $\begin{array}{l}\text { B-F5 } \\
\qquad(x=0.407)\end{array}$ & $\begin{array}{r}5.89 \\
3.92 \\
1.96 \\
\lim 0\end{array}$ & $\begin{array}{l}2.73 \\
1.65 \\
0.73\end{array}$ & $\begin{array}{l}0.464 \\
0.421 \\
0.372 \\
0.330\end{array}$ & 75,430 & 9.24 & 0.356 \\
\hline $\begin{array}{l}\text { B-F2 } \\
(x=0.574)\end{array}$ & $\begin{array}{l}6.01 \\
4.01\end{array}$ & $\begin{array}{l}2.50 \\
1.40\end{array}$ & $\begin{array}{l}0.416 \\
0.348\end{array}$ & & 9.24 & 0.343 \\
\hline
\end{tabular}




\begin{tabular}{|c|c|c|c|c|c|c|}
\hline & $\begin{array}{r}2.00 \\
\lim 0\end{array}$ & 0.67 & $\begin{array}{l}0.335 \\
0.270\end{array}$ & 92,150 & & \\
\hline $\begin{array}{l}\text { C-F2 } \\
\quad(x=0.686)\end{array}$ & $\begin{array}{r}5.78 \\
3.85 \\
1.93 \\
\lim 0\end{array}$ & $\begin{array}{l}2.71 \\
1.93 \\
0.83\end{array}$ & $\begin{array}{l}0.468 \\
0.501 \\
0.433 \\
0.390\end{array}$ & 63,820 & 10.90 & 0.311 \\
\hline $\begin{array}{l}\text { PVC-F3 } \\
\quad(x=1.00)\end{array}$ & $\begin{array}{r}5.96 \\
3.97 \\
1.99 \\
\lim 0\end{array}$ & $\begin{array}{l}3.09 \\
1.86 \\
0.86\end{array}$ & $\begin{array}{l}0.470 \\
0.427 \\
0.391 \\
0.361\end{array}$ & 68,940 & 6.71 & 0.361 \\
\hline
\end{tabular}

共重合体溶液中の高分子成分 1 および 2 ，ならびに溶媒 3 のそれぞれの容積分率を $v_{1}, v_{2}, v_{3}$ とすれば上表 に得られる \% は次式に従うものである。ただし $P$ は共重合体のモル容積と溶媒のそれとの比である。共重

$$
\pi=-\frac{R T}{V_{3}}\left[\ln v_{3}+\left(1-\frac{1}{P}\right)\left(1-v_{8}\right)+\chi\left(v_{1}+v_{2}\right)^{2}\right]
$$

合体の組成, 重合度が全く均一であり, 成分の単位の大きさも同一であるような場合は, お㧍ざっぱな近似 で共重合体溶液は高分子 1-高分子 2-溶媒 3 の 3 成分采と同様に取り扱われる゙。

$$
\pi=-\frac{R T}{V_{3}}\left[\ln v_{3}+\left(1-\frac{1}{P}\right)\left(1-v_{3}\right)+\chi_{18} v_{1}^{2}+\chi_{28} v_{2}{ }^{2}+\left(\chi_{18}+\chi_{28}-\chi_{12}\right) v_{1} v_{2}\right]
$$

それ故共重合体に対する \%は成分対のそれらと次の関倸にあることになる。

$$
\chi=\chi_{13} \theta_{1}+\chi_{23} \theta_{2}-\chi_{12} \theta_{1} \theta_{2}
$$

ただし $\theta_{1}=v_{1} /\left(v_{1}+v_{2}\right), \theta_{2}=v_{2} /\left(v_{1}+v_{2}\right)$ である。

みを共重合体中の塩化ビニルの容積分率 $\theta_{1}$ に対して図示 すると第 1 図のようになる。PVC, PVAc の単一重合体に関 し $\chi_{13}=0.361, \chi_{23}=0.477$ であるから共重合体に得られた表 の $\chi$ の価により(2)式から $\chi_{12}$ の平均值として 0.450 が得 られる。第 1 図の曲線はこれらの数值を用いて求められた (2)式の計算曲線である。曲線は下に凸で $\theta_{1}=0.7$ 付近に極 小がある。 $れ-\theta_{1}$ 曲線の直線関倸より負の偏位は定性的にい って，共重合体成分 1 と 2 の間がエネルギー的にむしろ排他 的に作用している結果といえる。このような効果が $\chi と \theta_{1}$ の直線関倸より以上に共重合体の溶解性を良くしている原因 であるわけである。

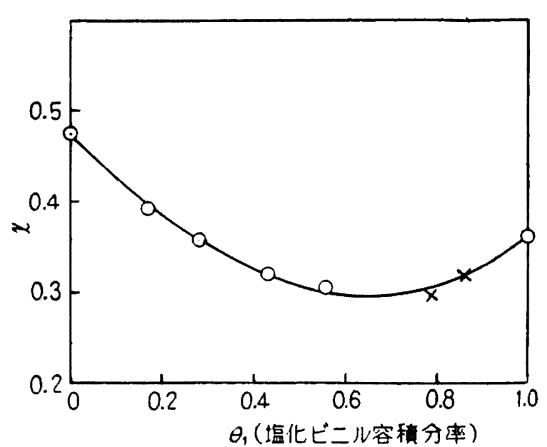

第 1 図 VAc-VC 共重合体シクロー キサノン溶液の $\chi$ の共重合体組成 依存性, $30^{\circ} \mathrm{C}, \times$ 印は先報” の結果

われわれの発表(1954 年 5 月) とほとんど同一時に河合ら2)も同一の采について浸透圧測定を行い，ほぼ同 様の結論を得ているが，氏らの％はいずれも本報の対応する值より若干大であり，また $x$ の 05 以上の共重 合体で(2)式よりの偏位が指摘されている。氏らはこの偏位が試料の組成的不均一性によるかもしれないこ とを示唆しているが，本報で用いた共重合体はその調製過程から考えて無秩序共重合体といえるもので，鎖 中の成分分布になんら規則性を考虑する必要はないものと考えられる。実駼点も少なく，現段階ではより立 入った検討を行らことは尚早であろら。希釈熱あるいは浸透圧の温度傾斜について結果が得られてから 
エントロピーおよび熱項の寄与を分離し，しかる後これらの点について論義したいと考える。

\section{4. 共重合体の浴解性ならびに溶解状態}

共重合体の溶解性が直線関倸よりも良好になることは $\chi$ の変化から前節で論じたが，ここでは限界点におけ る溶媒組成, 極限粘度数 $[\eta]$ の温度依存性などの面か ら検討する。石油ベンジンは VAc-VC 系に対 しては 非溶媒である。一定温度で, 一定濃度の共重合体シク口 ヘキサノン溶液に石油ベンジンを添加してゆくと，初め 共重合体はシクロへキサノンのみの場合より,よりよ い溶解状態にもたらされ，極大の溶解状態を経て終に沈 殿してくる。沈殿点の少し以前で溶液は螢光を発してく るが，これはまさに 2 相への分離が起ろうとする限界点 である。限界点における混合溶媒組成を共重合体組成に 関して図示すると第 2 図のごとく $\theta_{1}$ の增加とともに非 溶媒含率は增加し， $\theta_{1}=0.7$ で極大をもつような曲線が 得られた。これは第 1 図に示した結果とまったく一致し ている。限界点においては近似的に $A_{2}=0$ と扔けるか らこの点における $[\eta]$ の值は 熱力学的取扱上の規準にと れる。それらを第 4 表に示す。

第 4 表 限界組成にお汁る極限粘度数 $[\eta]_{c}, 30^{\circ} \mathrm{C}$

\begin{tabular}{c|ccccc}
\hline \hline 試料 & PVAc-F3 & A-F3 & B-F2 & C-F2 & PVC-F3 \\
\hline$[\eta]_{c}$ & 0.048 & 0.026 & 0.022 & 0.027 & 0.062 \\
\hline
\end{tabular}

溶液中におけす分子の広がりの規準状態におけるそれ

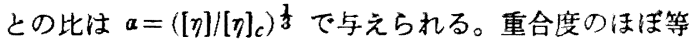
しい共重合体に関してaは共重合体組成について比較 できる量である。 $30^{\circ} \mathrm{C}$ のシクロへキサノン溶液の $\alpha を$ 第 5 表㑝仁した。

シクロヘキサノン溶液 $[\eta]$ の温度依存性を第 5 表およ び第 3 図に示す。

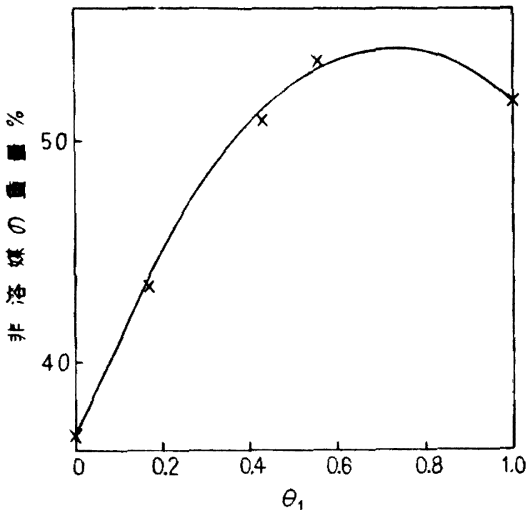

第 2 図限界点における溶媒組成の共重 合体組成依存性, $30^{\circ} \mathrm{C}, 3 \mathrm{~g} / 100 \mathrm{cc}$ 共重 合体シクロヘキサノン溶液に非溶媒と して石油ベンジンを添加し, 限界点に おける混合溶媒の組成を石油ベンジン の重量\%で示した。

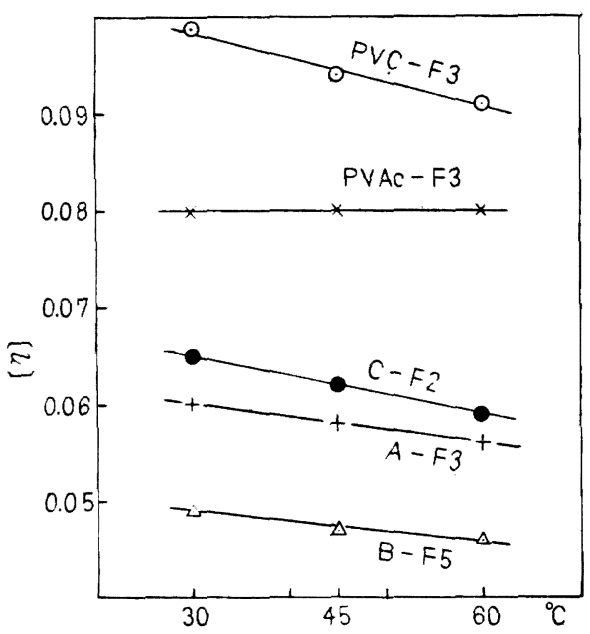

第 3 图 VAc-VC 共重合体のシクロへキサ ノン溶液極限粘度数の温度依存性

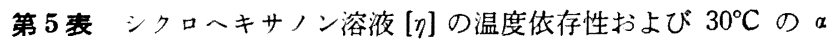

\begin{tabular}{|c|c|c|c|c|}
\hline & \multicolumn{3}{|c|}{$[\eta]$} & \multirow{2}{*}{ 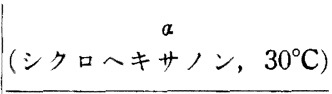 } \\
\hline & $30^{\circ} \mathrm{C}$ & $45^{\circ} \mathrm{C}$ & $60^{\circ} \mathrm{C}$ & \\
\hline PVAc-F3 & 0.080 & 0.080 & 0.080 & 1.186 \\
\hline$A-F 3$ & 0.060 & 0.058 & 0.056 & 1.321 \\
\hline
\end{tabular}




\begin{tabular}{l|l|l|l|l} 
B-F2 & 0.049 & 0.047 & 0.046 & 1.306 \\
C-F2 & 0.065 & 0.062 & 0.059 & 1.340 \\
PVC-F3 & 0.099 & 0.094 & 0.091 & 1.169 \\
\hline
\end{tabular}

ポリ酢酸ビニル単一高分子の場合 $[\eta]$ は $30 \sim 60^{\circ} \mathrm{C}$ の範囲で不変であるが塩化ビニル基の高分子鎖中への導 入によって $[\gamma]$ は温度上昇とともに減少しており， $[\eta]$ と温度の間にほほぼ直線関倸がみられる。温度上昇と

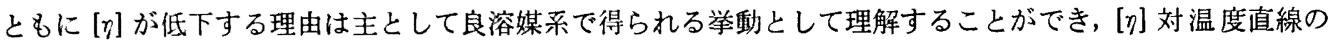
傾斜が大なるほどこの傾向が大であるといえる。この傾斜が A-F3，B-F5, C-F2 の順で大となっているの は前節の $\%$ の減少する結果によって説明される。PVAc-F3 で [ク] が温度により変化しないことはシクロへ キサノンがむしろ貧溶媒的であることを示すものである。

VAc-VC 共重合体の溶解性がより良好な方向に偏位しているということは以上に述べたような VAc-VC 間の相互作用によるものと理解してよいわけである。シクロへキサノン溶液について $A_{2}=0$ であるような

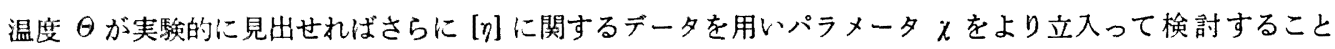
が可能である゙1のであるが, シクロへキサノンはVAc-VC 共重合体に対しては良溶媒であり $\Theta$ は $[\eta$ から は求めることはできなかった。

付 記：本報は高分子学会年次大会(1954 年 5 月 30 日, 東京)で報告した。

\section{文献}

1) 中島章夫, 中保治郎：高化, 9, 1 (1952)

2) 前田弘邦, 河合徹, 山口力：日化年会 (1954 年 4 月, 東京) で講演; 工化, 58, 502(1955)

3) P.J. Flory and W.R. Krigbaum: J. Chem. Phys., 18, 1086(1950)

4) 桜田一郎, 中島章夫：最近の化学とその応用, p. 173(Sep. 1954); 中島章夫, 外林秀人：高分子学会 年次大公, 東京 (1954年 5 月 30 日)

5) P. J. Flory: Principles of Polymer Chemistry, p. 611 (1953)

\section{Studies on the Solution of Vinylcopolymer}

\section{Osmotic Pressure and Viscosity of Vinylacetate-Vinylchloride Copolymer Solutions}

By Akio Nakajima, Hideto Sotobayashi and Ichiro Sakurada

Osmotic pressure and viscosity of vinylacetate-vinylchloride copolymer were measured in cyclohexanone. Relation between the molecular weight and the intrinsic viscosity, and the thermodynamic properties of copolymer were discussed as function of polymer composition. 